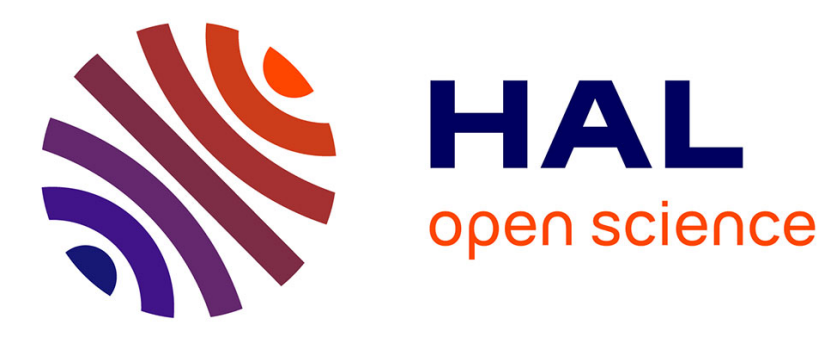

\title{
Platform GenoSol: a new tool for conserving and exploring soil microbial diversity
}

Samuel S. Dequiedt, Mélanie M. Lelievre, Pierre-Alain Maron, Christophe

Mougel, Nicolas Chemidlin Prévost-Bouré, Fabien Morin, Aurore Cecchetto, Claudy C. Jolivet, Dominique Arrouays, Philippe P. Lemanceau, et al.

\section{To cite this version:}

Samuel S. Dequiedt, Mélanie M. Lelievre, Pierre-Alain Maron, Christophe Mougel, Nicolas Chemidlin Prévost-Bouré, et al.. Platform GenoSol: a new tool for conserving and exploring soil microbial diversity. 4ème Colloque de l'Association Francophone d'Ecologie Microbienne (AFEM), Aug 2009, Lyon, France. 1 p. hal-01137004

\section{HAL Id: hal-01137004 https://hal.science/hal-01137004}

Submitted on 8 Mar 2017

HAL is a multi-disciplinary open access archive for the deposit and dissemination of scientific research documents, whether they are published or not. The documents may come from teaching and research institutions in France or abroad, or from public or private research centers.
L'archive ouverte pluridisciplinaire HAL, est destinée au dépôt et à la diffusion de documents scientifiques de niveau recherche, publiés ou non, émanant des établissements d'enseignement et de recherche français ou étrangers, des laboratoires publics ou privés. 
S. Dequiedt ${ }^{1,2}$, M. Lelievre ${ }^{1,2}$, P.A. Maron ${ }^{1,2}$, C. Mouget ${ }^{1,2}$, N. Chemidlin Prevost-boure ${ }^{1,2}$, F. Morin ${ }^{1,2}$, A. Cecchetto ${ }^{1,2}$, C. Jolivet ${ }^{3}$, D. ARRouays ${ }^{3}$, P. LemanceaU ${ }^{1,2}$, L. RANJARD ${ }^{1,2}$

Contact : lionel.ranjard@dijon.inra.fr

1 Plateforme GenoSol, INRA, Université de Bourgogne, CMSE, 17 rue Sully, B.V. 86 510, 21065 DIJON Cedex - FRANCE 2 INRA, Université de Bourgogne, UMR Microbiologie du Sol et de l'Environnement, CMSE, 17 rue Sully, B.V. 86510,21056 DIJON Cedex - FRANCE ${ }^{3}$ INRA Orléans - US 1106, Unité INFOSOL, Avenue de la Pomme de Pin, B.P. 200 619, Ardon, 45166 OLIVET Cedex - FRANCE

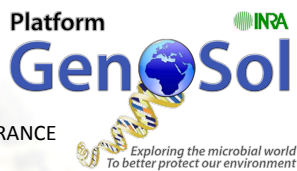

\section{Scientific context}

Soils are the principal reservoirs of microbial diversity and represent a core component of terrestrial ecosystems. There is an increasing demand for assessing the impact of agricultura and industrial practices on the environment at large scales in a context of global change. To address this demand taxonomic and functional diversity of soil microbial communities, and their stability over time, need to be characterized to better predict soil quality. Recent methodological progresses have led to the development and automation of molecular biological tools (based on

the extraction and characterization of nucleic acids), which now allow their application to large scale samplings making possible the production of a reliable reference system for the characterization and interpretation of the soil microbial diversity. In this context, the Platform GenoSol was created in 2008 by the Research Unit of INRA (National Institute for Agronomic Research) " Microbiology of the Soil and Environment » in Dijon (France).

\section{The First "Biological" Soil Conservatory}

The aim of this platform is to provide an appropriate logistic structure for the acquisition, storage and characterization of soil genetic resources obtained by extensive sampling (several hundred to several thousand soils), on very large space and/or time scales (network of national soil survey, long-term experimental sites, ...), and to make these resources readily available for the whole scientific community and policy makers. The ultimate goal is to produce a reliable

reference system based on molecular characterization (taxonomic and functional features) of the soil microbial communities that provide scientific interpretations of the analyses from large scales of time and space sampling. The platform also aims at building up and storing for longterm periods a library of soil genetic resources that is made available to national and international scientific communities = first "biological" soil conservatory.

\section{Technical and scientific objectives}

\section{Technical and logistical tools}

Expertise in soil sampling strategies

Extraction, storage of soil DNA library, management and provision of soil DNA samples originated from large-scale sampling

Characterization of genetic resources (taxonomic diversity, functional potential)

Management of a database ('MicroSol') that collects and makes available the genetic resources data

Provision of an analytical reference system (statistical tools, modelling, bioinformatics)

- Technological surveillance of the tools used in the molecular characterizations and mathematical analyses and

Training in the use of molecular tools and data analysis

\section{Scientific Outputs}

Distribution and inventory of microbial diversity at large scales Evaluation of the relevance of the different microbialbiogeography hypotheses ('everything is everywhere', taxa-area relationship, biogeographical distribution patterns, ...) Evolution of microbial diversity under different environmental pressures (change of land use such as short crop rotation vs monoculture, climatic change, ... Relation between microbial diversity and soil functioning and quality Identification of microbiological indicators of soil quality and soil evolution Progresses in the understanding of the role of biodiversity in agroecosystemics goods and services Environmental metagenomic and Post Genomic studies

\section{Diagram of the technical and logistical support}

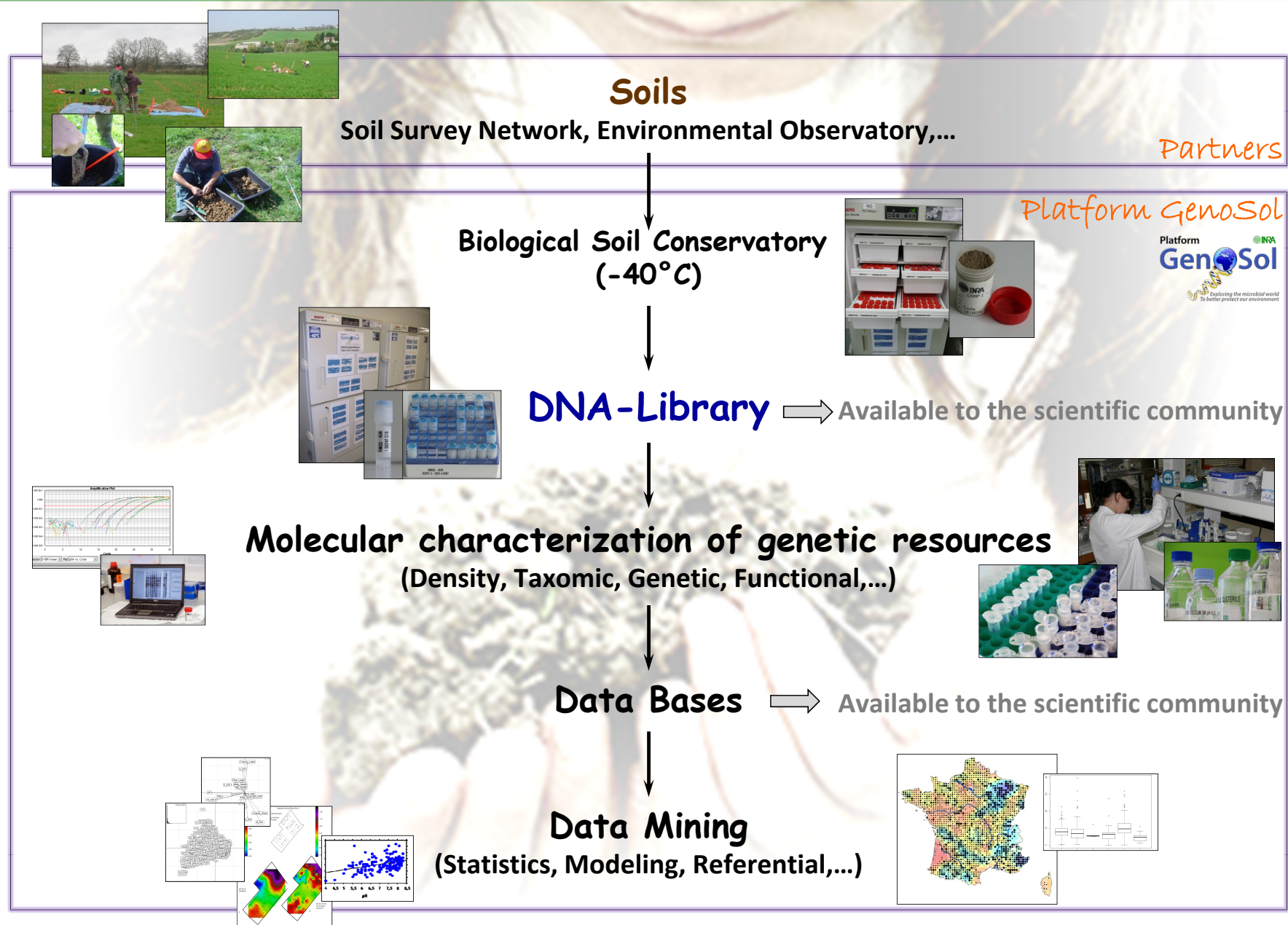

